\title{
Öğretmen Adaylarının Kültürlerarası Duyarlılıklarının Empatik Ĕgilim, Öznel İyi Oluş ve Sosyo-Demografik Değişkenler Açısından İncelenmesi*
}

\author{
Examining Intercultural Sensitivity in terms of Empathic \\ Tendency, Subjective Well-Being and Socio-Demographic \\ Variables among Teacher Candidates*
}

\begin{abstract}
Ayten BÖLÜKBAŞI**
Öz: Bu araştırmanın amacı öğretmen adaylarının empatik eğilim ve öznel iyi oluş puanlarının kültürlerarası duyarlılık puanlarını yordamadaki katkılarını inceleyerek kültürlerarası duyarlılık puanlarının cinsiyet, öğrenim gördükleri program, yurtdışı deneyimi, algılanan yabancı dil düzeyi, farklı ülke ya da kültürlerden tanıdıklara ve yakın arkadaşlara sahip olma sosyo-demografik değişkenleri açısından farklılaşıp farklılaşmadığını incelemektir. Araştırmanın çalışma grubunu, Akdeniz Bölgesindeki bir devlet üniversitesinin eğitim fakültesinin farklı programlarından 253'ü (\%71.3) kadın ve 102'si (\%28.7) erkek olmak üzere toplam 355 öğretmen adayından oluşmaktadır. "Kültürlerarası Duyarlılık Ölçeği”, "Empatik Eğilim Ölçeği”," "Yaşam Doyumu Ölçeği”, "Olumlu-Olumsuz Duygu Ölçeği”, "Kişisel Bilgi Formu" kullanılarak toplanan verilerin analizinde korelasyon analizi, çoklu regresyon analizi, bağımsız gruplar için t-testi, tek yönlü varyans analizi kullanılmıştır. Araştırmanın veri analizi sonuçlarına göre, öğretmen adaylarında kültürlerarası duyarlılık, empatik eğilim ve öznel iyi oluş arasında pozitif yönlü anlamlı ilişkiler tespit edilmiștir. Ayrıca, empatik eğilim ve öznel iyi oluşun, kültürlerarası duyarlılığın anlamlı birer yordayıcısı olduğu ortaya konulmuştur. Sosyo-demografik değişkenler açısından ise öğretmen adaylarında kültürlerarası duyarlılıkta cinsiyete göre anlamlı farklılaşma tespit edilmezken öğrenim gördükleri program, yurtdışı deneyimi, algılanan yabancı dil düzeyi, farklı ülke ya da kültürlerden tanıdıklara ve yakın arkadaşlara sahip olma değişkenleri açısından anlamlı farklılaşma tespit edilmiştir.
\end{abstract}

Anahtar Kelimeler: Kültürlerarası duyarlılık, empatik eğilim, öznel iyi oluş, öğretmen adayları

\begin{abstract}
The purpose of this study is to examine predictive power of empathy and subjective well-being on intercultural sensitivity among teacher candidates. Another purpose in this study is to examine whether intercultural sensitivity differs in terms of some socio-demographic variables such as gender, teaching program type, going abroad experience, perceived language level and having acquaintances or close friends from different national or cultural backgrounds. The study group consists of 355 teacher candidates (253 females $71.3 \%, 102$ males 28.7\%) from different teaching training departments of Faculty of Education in a state-funded university on the Mediterranean region of Turkey. The "Intercultural Sensitivity Scale," the "Empathic Tendency Scale", the "Satisfaction with Life Scale" and "Positive and Negative Affect Schedule" and finally, the "Personal Information Form" were used for data collection. In data analysis, correlation analysis, multiple regression analysis, independent samples t- test and one-way analysis of variance (ANOVA) were performed. Findings of the study demonstrated that intercultural sensitivity, empathic tendency and subjective well-being were all positively correlated with each other among teacher candidates. Other findings of this study indicated that empathic tendency and subjective well-being were found to be significant predictors of intercultural sensitivity among teacher candidates. According to sociodemographic variables results, although intercultural sensitivity scores did not differ significantly in terms of gender, significant difference has been found for teaching program type, going abroad experience,
\end{abstract}

\footnotetext{
*Bu çalışmanın bir kısmı, 18-22 Nisan 2018 tarihleri arasında düzenlenen 27. Uluslararası Eğitim Bilimleri Kongresi'nde sözlü bildiri olarak sunulmuştur.

** Doktora Öğrencisi, Çukurova Üniversitesi, Eğitim Fakültesi, Adana-Türkiye, ORCID: 0000-00034102-3906, e-posta: ayten.bolukbasi2@gmail.com
} 
perceived foreign language level and having acquaintances or close friends from different national or cultural backgrounds among teacher candidates.

Keywords: Intercultural sensitivity, empathic tendency, subjective well-being, teacher candidates

\section{Giriş}

Günümüzde ekonomi, sosyal, politika ve eğitim gibi temel alanlardaki yenilikler doğrultusunda insanların artık daha fazla kültürlerarası temas, iletişim ve etkileşimde bulunması söz konusu olmaktadır. Aday öğretmenler, öğretmenlik mesleği uygulamalarına başlamadan önce çeşitliklerin arttı̆̆ öğrenci özellikleri ile değişen sosyal, kültürel ve entelektüel eğitim taleplerini karşılayabilecek deneyimlere ihtiyaç duymaktadır (Milner, 2010a). Kültürel olarak çeşitliliğin artmasıyla beraber etkili eğitim sunulabilmesi ve eşit eğitim imkanı için kültüre duyarlı öğretmenlere günümüzde ihtiyaç gittikçe artmaktadır. Kültüre duyarlı olma özelliği olmayan öğretmenler sınırlı kültürlerarası bilgi ve duyarlılığa sahiptir. Ayrıca öğrencilerin kültürlerinin, bu öğrencilerin öğrenmelerini önemli düzeyde etkilediğinin yeterince farkında değillerdir. Kültürel olarak çeşitliliğe sahip öğrencilerin kültürel deneyimlerini akademik öğrenmeleri ile yeterince bağdaştıramamaları öğrencilerin anlamlı öğrenme deneyimlerinden mahrum kalmalarına neden olabilmektedir (Ruan, 2014). Öğrencilerin eşit eğitim şartlarından yararlanabilmesi ve demokratik öğrenme ortamlarına ulaşabilmesi için öğretmenlerin kültürel farkl11ıklara duyarlılığa sahip olması önem taşımaktadır (Ünlü ve Örten, 2013).

Farklı kültürden insanların kendi kültürlerini ve diğer kültürleri sorgulamak ve tanımak için etkileșimde bulundukları dinamik süreç "kültürlerarası" kavramını yansıtmaktadır (James, 2008). Kültürlerarası kavram1, farklı kültürlerden gelen insanların birbiriyle olan etkileşimindeki iletişim yeteneğini vurgulamaktadır. Kültürlerarası iletişim yeterlilik tanımı çalışılmak istenen bilim alanları ve yaklaşımlara göre değişmekle birlikte Spitzberg ve Changnon (2009) tarafından "bilişsel, duyuşsal ve davranışsal olarak farklı uyumlar gösteren bireylerin aralarındaki etkileşimin etkili ve uygun olarak yönetebilmesi” olarak tanımlanırken, Vilà (2010) tarafındansa "kültürel anlamlar ile uzlaşabilme ve etkili iletişimi sürdürebilme davranışları" olarak tanımlanmıştır.

Kültürlerarası iletişim modeli (Chen ve Starosta, 1996) kültürlerarası duyarlılık, kültürlerarası farkındalık ve son olarak kültürlerarası beceriklilik olmak üzere üç boyuttan oluşmaktadır ve duygulara işaret eden duyuşsal boyutunda yer alan kültürlerarası duyarlılık kavramı, kültürlerarası iletişim yeterliliğinin ön koşulu olarak kabul edilmektedir (Fritz, Mollenberg ve Chen, 2002). Chen ve Starosta (1996) kültürlerarası duyarlılığı, "bireyin iletişimde uygun ve etkili bir davranışı teşvik eden kültürel farkl1lıkları anlama ve takdir etme yönünde olumlu bir duygu geliştirme yeteneği” olarak ifade etmiştir. Kültürlerarası duyarlılık, duyuşsal, bilişsel ve davranışsal etkileşimler ile ilişkili olmakla birlikte temelde duygular ile daha çok ilgilenmektedir (Chen, 1997). Bu kavramın farklı yaklaşımlar ile ortak olarak nasıl kavramlaştığına bakıldığında, diğer kültürlere olan merak, kültürel farklılıkları fark etme ve anlama ve bunların yanı sıra bireyin davranışlarını düzenlemeye olan isteklilik şeklinde ön plana çıktığı ifade edilmektedir (Hammer, Bennett ve Wiseman, 2003).

Hollins'e (2015) göre genellikle geleneksel olarak bir toplumun baskın kültürü dikkate alınarak hazırlanan müfredat programları ile kültürel çeşitliliğe sahip öğrenciler arasındaki uyumsuzluğun azalmasında öğretmenlerin kültüre duyarlı öğretimi merkeze alması önemli bir role sahiptir. Bu tür bir duyarlılı̆̆a sahip öğretmenlerin yetiştirilmesinde hizmet öncesi eğitim süreci olan öğretmenlik lisans programlarına önemi büyüktür (Hermans, 2002; Jones, 2002). Özellikle de öğretmen yetiştiren bu programlardaki öğretim elemanlarına, müfredatlarını hazırlarken öğrenmede kültürlerarası süreci dikkate alıp gerekli değişiklikleri yapmalarında (McAllister ve Irvine, 2000) ve aday öğretmenlerin kültürlerarası yeterlilik ve becerilere sahip olmasını sağlamalarında oldukça önemli görevler düşmektedir (Yuen ve Grossman, 2009). Bu noktada, kültürel farklılıkları dikkate alarak hazırlanan müfredatın öğrencilerin akademik başarılarının yanı sıra kişisel ve kültürlerarası yeterliliklerinin gelişimlerine de katkı sağlayacağ 1 düşünülmektedir (Otten, 2003; Talib, 2006). 
Öğretmenlerin bir kısmı, farklı dil ve kültüre sahip öğrencilere uygun tutumlar sergileyebilirken, bunu gerçekleştiremeyen diğer bir kısım öğretmenler ise olumsuz önyargılara sahip olup öğrencilerden beklentilerini düşürmeleri söz konusu olabilmektedir. Öte yandan, bazı durumlarda öğretmenlerin farklı kültüre sahip öğrencilerin kapasitesinin yeterliliğine inanmalarına rağmen bu öğrencilerin öğretim sürecinde kendilerini geliştirmelerine yardımcı olabilecek bilgi ve stratejilere sahip olamayabilmektedir (Bhavnagri, 2001).Yabanc1 uyruklu öğrencilerin yanı sıra kültürel olarak farklı özelliklere sahip öğrenciler öğretmenlerinin kültürlerarası duyarlılık seviyesinden etkilenmekte ve kültüre duyarlı öğretimden daha fazla verim alabilmektedir (Gay, 2010).

Öğretmenler için öğrencilerin okul ve okul dıșında da deneyimledikleri kültürel norm ve değerler arasında bağ işlevi (Howard, 2006; Ladson-Billings, 2006; McAllister ve Irvine, 2002; Milner, 2010b) sağlayan kavramın "empati" olduğu ifade edilebilir. Empati, "bir insanın, kendisini karşısındaki insanın yerine koyarak onun duygularını ve düşüncelerini doğru olarak anlamasıdır" (Dökmen, 1994) ve empatinin duygusal boyutunu yansıtan empatik eğilim de "bireylerin günlük hayatlarındaki empati kurma potansiyeli" olarak ifade edilmektedir (Dökmen, 1988). Empati, çok kültürlü sınıf düzeninde öğrencilerin öğrenme sonuçlarını geliştirmede önemli bir müdahale olarak görülmektedir (Dolby, 2012). Günümüzün beraberinde getirdiği koşullar açısından değerlendirildiğinde, kaçınılmaz olarak çeşitli kültürlerde eğitim verecek olan aday öğretmenlerde empatinin, öğretmenlik meslek eğitiminde öğrenilmesi gereken özelliklerden birisi olduğu vurgulanmaktadır (Aspy, 1975; Black ve Phillips, 1982; Tettegah ve Anderson 2007). Kültürlerarası duyarlılıkta merkezi bir role sahip olan empatinin aracılı̆̆ 1 ile birey iletişimde olduğu kişinin duygu ve ifadelerine duyarlılık geliştirmekte ve aktif dinleme ile anladığına yönelik tepkiler verebilmektedir (Chen, 1997).

Alanyazın incelendiğinde kültürlerarası duyarlılık ve empatiye yönelik yapılan çalışmaların çoğunlukla üniversite öğrencileri, hemşire meslek grubu ve hemşirelik öğrencileri ile öğretmen ve öğretmen adayları ile gerçekleştirilmiş olduğu ifade edilebilir. Yapılan çalıșmalarda kültürlerarası duyarlılık ile empati arasında pozitif yönde anlamlı ilișkiler saptanmıştır (Egelioğlu Çetişli ve diğerleri, 2016; Ekong, Kavookian ve Hutchison, 2017; Kürtüncü, Arslan, Çatalçam, Yapıcı ve Hırçın, 2018; Menardo, 2017). Öte yandan halk eğitim merkezindeki öğretmenler ile yapılan bir araştırmada kültürlerarası duyarlılık ve empatik eğilim arasında anlamlı bir ilişki gözlenmemiştir (Güner ve Levent, 2018).

Kişilerin kendilerini hem iyi hissetmeleri hem de kişilerarası ilişkilerde de daha başarılı olmalarına katkı sağlayan (Diener ve Seligman, 2002) öznel iyi oluş, yaşamdan doyum alma, olumlu duyguları sık ve olumsuz duyguları az yaşamanın ifadesi olarak tanımlanmıştır (Argyle, Martin ve Crossland, 1989; Diener, 1984). İnsanların kendi yaşamlarını değerlendirmesini yansıması olan öznel iyi oluş kavramı, günlük hayatta sıklıkla mutluluk olarak bilinmektedir (Lucas ve Diener, 2008). Öznel iyi oluşun bilişsel boyutunu oluşturan yaşam doyumu, bireylerin kişisel kriterlerine göre ve genel olarak yaşam kalitelerini değerlendirmesi sonucu vardığ 1 yargıyı yansıtmaktadır (Pavot ve Diener, 1993). Duyuşsal boyutta ise olumlu ve olumsuz duyguların değerlendirmesi yapılmaktadır (Diener, 1984). Öznel iyi oluşun sosyal ilișkiler üzerindeki olumlu etkileri açısından değerlendirildiğinde bireylerin çevresinde insanlar bulunduklarında daha mutlu oldukları (Kahneman ve Krueger, 2006) ve diğerleri ile birlikte olduklarında daha fazla olumlu duygulanım ifade etme eğiliminde oldukları ortaya konmuştur (Diener ve Biswas-Diener, 2008). Alanyazını incelendiğinde mutluluğun ve kültürlerarası duyarlılığın pozitif yönde anlamlı ilişkiye sahip olduğu (Öğüt, 2017) ve kültürlerarası duyarlılık, empati ve öznel iyi oluşun bilişsel boyutu olan yaşam doyumu arasında pozitif yönlü anlamlı ilişkiler olduğu görülmektedir (Micó-Cebrián ve Cava, 2014).

Tüm bu açıklamalar 1şığında mevcut araştırma, kültürlerarası duyarlılık, empatik eğilim ve öznel iyi oluş değişkeni ile sosyo-demografik değişkenlerle birlikte alanyazınında incelenen ilk çalışma olma özelliği taşımaktadır. Aynı zamanda bu çalışmadan elde edilecek bulgular doğrultusunda öğretmen yetiştiren üniversitelerin eğitim fakültelerinde öğrenimlerine devam etmekte olan öğretmen adaylarının ve Milli Eğitim Bakanlığı'na bağlı farklı öğretim 
kademelerindeki okullarda çalışmakta olan öğretmenlerin kültürlerarası duyarlılıklarının geliştirilmesine yönelik öneriler sunulabilecektir.

\section{Araştırmanın amacı}

Bu araştırmanın genel amacı, öğretmen adaylarının; empatik eğilim ve öznel iyi oluş puanlarının kültürlerarası duyarlılık puanlarını yordamadaki katkılarını inceleyerek, kültürlerarası duyarlılık puanlarının cinsiyet, öğrenim gördükleri program, yurtdışı deneyimi, algılanan yabancı dil düzeyi, farklı ülke ya da kültürlerden tanıdıklara ve yakın arkadaşlara sahip olma değişkenleri açısından farklılaşıp farklılaşmadığını incelemektir. Bu genel amaç doğrultusunda aşağıdaki sorulara yanıt aranmıştır:

1. Öğretmen adaylarının empatik eğilim ve öznel iyi oluş puanları kültürlerarası duyarlılık puanlarını yordamakta midır?

2. Öğretmen adaylarının kültürlerarası duyarlılık puanları cinsiyetlerine göre farklılaşmakta midir?

3. Öğretmen adaylarının kültürlerarası duyarlılık puanları öğrenim gördükleri programlarına göre farklılaşmakta mıdır?

4. Öğretmen adaylarının kültürlerarası duyarlılık puanları yurtdışı deneyimlerine göre farklılaşmakta midır?

5. Öğretmen adaylarının kültürlerarası duyarlılık puanları algılanan yabancı dil düzeyine göre farklılaşmakta mıdır?

6. Öğretmen adaylarının kültürlerarası duyarlılık puanları farklı ülke ya da kültürlerden tanıdıklara sahip olmalarına göre farklılaşmakta mıdır?

7. Öğretmen adaylarının kültürlerarası duyarlılık puanları farklı ülke ya da kültürlerden yakın arkadaşlara sahip olmalarına göre farklılaşmakta mıdır?

\section{Yöntem}

\section{Araştırma modeli}

Bu araştırmada, öğretmen adaylarının; empatik eğilim ve öznel iyi oluş puanlarının kültürlerarası duyarlılık puanlarını yordamadaki katkılarını inceleyerek, kültürlerarası duyarlılık puanlarının cinsiyet, öğrenim gördükleri program, yurtdışı deneyimi, algılanan yabancı dil düzeyi, farklı ülke ya da kültürlerden tanıdıklara ve yakın arkadaşlara sahip olma değişkenleri açısından farklılaşıp farklılaşmadığının incelenmesi amaçlandığı için, betimsel yöntemle yapılmış ilişkisel tarama modeli kullanılmıştır. Araştırmanın bağımlı değişkeni kültürlerarası duyarlılık puanlarıyken, bağımsız değişkenleri empatik eğilim, öznel iyi oluş ve cinsiyet, öğrenim gördükleri program, yurtdışı deneyimi, algılanan yabancı dil düzeyi, farklı ülke ya da kültürlerden tanıdıklara ve yakın arkadaşlara sahip olmak gibi sosyo-demografik değişkenler oluşturmaktadır.

\section{Araştırma grubu}

$\mathrm{Bu}$ çalışmanın araştırma grubunu Akdeniz bölgesindeki bir devlet üniversitesinin eğitim fakültesinin farklı programlarında dördüncü sınıfa devam etmekte olup araştırmaya gönüllü olarak katılmayı kabul eden 253’ü (\% 71.3) kadın ve 102'si (\% 28.7) erkek olmak üzere toplam 355 öğretmen adayından oluşmaktadır. Araştırma grubunda yer alan öğretmen adaylarının yaş ranjı 20 ile 34 arasında değişmektedir.

\section{Veri toplama araçları}

$\mathrm{Bu}$ araştırma kapsamında veri toplama araçlarının kullanımına yönelik aşağıda sunulan ilgili ölçeklerin ilgili yazarlarından gerekli kullanım izinleri alınarak veriler toplanmıştır.

Kültürlerarası Duyarlılık Ölçeği (KDÖ): Chen ve Starosta (2000) tarafindan bireylerin kültürlerarası duyarlılık düzeylerini ölçmek amacıyla geliştirilen ölçek, 5'li (Likert tipi değerlendirmeye dayalı 24 madden oluşmaktadır. Ölçeğin Türkçe diline uyarlama çalışmasını 
Üstün (2011) gerçekleștirmiştir. KDÖ’nün 5 alt boyutunu Kültürlerarası Etkileşime Katılım (madde 1, 11, 13, 21, 22, 23, 24), Kültürel Farklılıklara Sayg1 Duyma (madde 2, 7, 8, 16,18, 20), Kültürlerarası Etkileşimde Özgüven (madde 3, 4, 5, 6, 10), Kültürlerarası Etkileşimden Zevk Alma (madde 9, 12, 15.), Kültürlerarası Etkileşime Özen Gösterme (madde 14, 17, 19) şeklindedir. Ayrıca, ölçeğin 2, 4, 7, 9, 12, 15, 18, 20 ve 22. maddeler ters çevrilmesi gereken maddelerdir. Orijinal ölçek için gerçekleştirilen güvenirlik çalışmasında iki ayrı uygulamada hesaplanan Cronbach Alfa katsayıları .86 ve .88 şeklinde bulunmuştur. Mevcut çalışma kapsamındaki araştırma grubu içinse ölçeğin toplam puanı için hesaplanan Cronbach Alfa değeri .88 olarak bulunmuştur.

Empatik Ĕgilim Ölçeği (EEÖ): Ölçek, Dökmen (1988) tarafından geliştirilmiş ve kişilerin günlük yaşantılarındaki empati kurma potansiyellerini ölçmeyi amaçlayan 5'li Likert tipi bir ölçektir. Empatik Eğilim Ölçeği'nin geçerlik güvenirlik çalışmasında güvenirlik katsayısı .82 olarak bulunmuştur. Ölçekten alınabilecek en yüksek toplam puan 100 iken, en düşük puan 20'dir. Alınan toplam puanın yüksek olması empatik eğilimin yüksek olduğu ifade etmektedir. Ölçek puanlamasında 1 "Tamamen aykırı" ve 5 "Tamamen uygun" şeklinde belirtilmiştir. Empatik eğilim ölçeğinde $3,6,7,8,11,12,13,15$. sırada yer alan maddeler ters maddelerdir. Bu çalışma kapsamındaki araştırma grubu için Cronbach Alfa değeri ise .71 olarak bulunmuştur.

Öznel İyi Oluşun Ölçümü: Bu araştırma kapsamında katılımcıların öznel iyi oluş düzeylerini belirlemek amaciyla "Yaşam Doyumu Ölçeği" ve "Olumlu-Olumsuz Duygu Ölçeği" kullanılmıştır. Öznel iyi oluş puanı hesaplanmadan önce değişkenlerden elde edilen puanlar öncelikle z puanlarına dönüştürülmüştür. Son olarak, öznel iyi olma puanı "yaşam doyumu + olumlu duygu -olumsuz duygu" formülünden yararlanılarak hesaplanmıştır.

Yaşam Doyumu Ölçeği (YDÖ): Diener, Emmons, Larsen ve Griffin (1985) tarafindan geliştirilen ölçek bireylerin yaşam doyumlarını ölçmeyi amaçlamaktadır. Likert tarzı 7 derecelidir (1 "kesinlikle katılmıyorum" ve 7 "kesinlikle katılıyorum") ve 5 maddeden oluşan ölçeğin Cronbach Alfa iç tutarlık katsayısı .87 , test-tekrar test güvenirlik katsayısı ise .82 olarak bulunmuştur. Ölçeğin Türkçe geçerlik ve güvenirlik çalışması Köker (1991) tarafından yapılmıştır. Köker (1991), ölçeğin üç hafta arayla uygulanan test tekrar test tutarlılık katsayısının .85 olduğunu raporlamıştır. Ölçekten alınabilecek en düşük puan $7 \mathrm{iken,} \mathrm{alınabilecek} \mathrm{en} \mathrm{yüksek} \mathrm{puan} \mathrm{ise} 35$ 'tir. Ölçekten alınan yüksek puanlar cevaplayıcının yaşam doyumunun yüksek olduğunu gösterirken ölçekten alınan düşük puanlar ise, yaşam doyumu düzeyinin düşük olduğunu göstermektedir. $\mathrm{Bu}$ çalışma kapsamındaki araştırma grubu için Cronbach Alfa iç tutarlılık güvenirlik katsayısı .86 olarak hesaplanmıştır.

Olumlu-Olumsuz Duygu Ölçeği: Watson, Clark ve Tellegen (1988) tarafından geliştirilen olumlu ve olumsuz boyutlarla duygu durumunu inceleyerek olumlu ve olumsuz duygulanımı ölçmeyi amaçlayan bir ölçektir. Ölçeğin olumlu duygularını; heyecanlı, güçlü, hevesli, gururlu, uyanık, ilhamlı, kararl1, aktif, ilgili ve dikkatli olmak oluştururken olumsuz duygularını da sıkıntılı, mutsuz, suçlu, ürkmüş, düşmanca, asabi, utanmış, sinirli, tedirgin ve korkmuş olmaktan oluşturmaktadır. Ölçekten elde edilen puanlar belirtilen duyguları yaşama sıklığına göre 5'li likert tipi ölçekle değerlendirilmektedir. Ölçek, toplamda 20 maddeden oluşmaktadır ve bu ölçeğin her iki boyutu için de en az 10 ve en çok 50 puan alınması mümkündür. Ölçeğin orijinalinde olumlu duygu boyutu için güvenirlik kat sayısı .88 ve olumsuz duygu boyutunun güvenilirlik kat sayıları .87 olarak hesaplanmıştır. Ölçeğin Türkçe uyarlama çalışmasını gerçekleştiren Gençöz (2000) faktör analizinde orijinal ölçeğe benzer bir şekilde iki faktör tespit etmiş ve bu yapı toplam varyansın \%44'ünü açıklamaktadır. Hesaplanan güvenilirlik katsayısı ise olumlu duygu için .86 ve olumsuz duygu için .83 olarak hesaplanmıştır. Mevcut araştırma kapsamındaki araştırma grubu içinse Cronbach Alfa iç tutarlılık güvenirlik katsayısı olumlu duygular için .79, olumsuz duygular içinse .80 olarak bulunmuştur. 
Kişisel Bilgi Formu: Katılımcıların cinsiyet, yaş, öğrenim gördükleri program, yurtdışı deneyimi, algılanan yabancı dil düzeyi, farklı ülke ya da kültürlerden tanıdıklara ve yakın arkadaşlara sahip olma değişkenlerine ilişkin bilgileri içeren bu form araştırmacı tarafindan sosyo-demografik değişkenleri ortaya koymak amaciyla oluşturulmuştur.

\section{İşlem}

Katılımcılara araştırmanın amacı ve gönüllülük esası ile ilgili gerekli bilgiler verildikten sonra, sınıf ortamında grup halinde iken bir ders saati süresinde araştırmacı tarafından hazırlanan kişisel bilgi formu ve diğer ölçekler uygulanarak gerçekleştirilmiştir. Araştırmadan elde edilen ölçme araçlarını tam ve uygun şekilde dolduran bireylerin verileri analize dahil edilmiştir. Ayrıca, bilimsel araştırma ve yayın etiğine aykırı eylemlerden hiçbiri gerçekleştirilmeden bu çalışma tamamlanmıştır.

\section{Verilerin analizi}

SPSS 20.0 paket programı kullanılarak gerçekleştirilen verilerin analizinde araştırmada incelenen değişkenlere ilişkin verilerin normal dağılması ve varyansların homojen olması nedeniyle veri analizi olarak parametrik testlerden yararlanılmıştır. $\mathrm{Bu}$ amaçla öncelikle, katılımcıların demografik özelliklerini ortaya koymak için yüzde ve frekanslar kullanılmıştır. Daha sonra ise araştırma grubunda yer alan ögretmen adaylarının kültürlerarası duyarlılık ve empatik eğilim ile öznel iyi oluş puanları arasındaki ilişkileri belirlemek üzere Pearson momentler çarpımı korelasyon katsayısı kullanılırken, empatik eğilim ile öznel iyi oluş puanlarının kültürlerarası duyarlılık puanlarını yordamadaki katkılarını belirlemek için çoklu regresyon analizi kullanılmıştır. Ayrıca öğretmen adaylarının kültürlerarası duyarlılık puanlarının cinsiyet, farklı ülke ya da kültürlerden tanıdıklara ve yakın arkadaşlara sahip olma değişkenlerine göre farklılaşıp farklılaşmadığını test etmek amacıyla bağımsız gruplar için $\mathrm{t}$ testi; öğrenim gördükleri program, yurtdışı deneyimi, algılanan yabancı dil düzeyine göre farklılaşıp farklılaşmadığını test etmek amacıyla ise tek yönlü varyans analizi (ANOVA) kullanılmıştır. Ortaya çıkan farkın kaynağını belirlemek amacıyla Scheffe testi kullanılırken, bağımsız değişkenlerin etki büyüklüğünü belirlemek için eta kare ( $\eta 2$ ) değerine bakılmıştır. Araştırmada hata payı 0.01 ve 0.05 olarak kabul edilmiştir.

\section{Bulgular}

Bu bölümde, araştırmanın alt amaçları doğrultusunda elde edilen bulgulara yer verilmiştir.

Öğretmen adaylarının empatik eğilim ve öznel iyi oluş puanlarının kültürlerarası duyarlıık puanlarını yordayıp yordamadığına yönelik bulgular

Öğretmen adaylarının empatik eğilim ile öznel iyi oluş puanları ile kültürlerarası duyarlık puanları arasındaki ilişkiyi ortaya koymak için öncelikle korelasyon analizi yapılmıştır. Daha sonra, öğretmen adaylarının empatik eğilim ve öznel iyi oluş puanlarının kültürlerarası duyarlık puanlarını yordamadaki katkılarını ele almak için verilere çoklu regresyon analizi uygulanmıştır.

Tablo 1.

Öğretmen Adaylarının Empatik Eğilim ve Öznel İyi Oluş Puanları ile Kültürlerarası Duyarlılık Puanları Arasındaki İlişkilere Yönelik Korelasyon Analizi Sonuçları

\begin{tabular}{llllll}
\hline Değişkenler & 1 & 2 & 3 & Ort. & \multicolumn{1}{l}{ Ss } \\
\hline $\begin{array}{l}\text { Kültürlerarası Duyarlılık } \\
\text { Empatik Eğilim }\end{array}$ & $.44 * *$ & - & & 90.66 & 10.31 \\
Öznel İyi Oluş & $.34 * *$ & $.54 * *$ & - & 68.57 & 8.12 \\
& & & & .06 & 2.14
\end{tabular}

$* * \mathrm{p}<.01$ 
Tablo 1 incelendiğinde, öğretmen adaylarının kültürlerarası duyarlılık puanlarının empatik eğilim $(\mathrm{r}=.44, \mathrm{p}<.01)$ ve öznel iyi oluş puanları $(\mathrm{r}=.34, \mathrm{p}<.01)$ arasında orta düzeyde pozitif yönde anlamlı ilişkisinin olduğu görülmektedir. Korelasyon analizi sonuçlarında görüldüğü gibi kültürlerarası duyarlılık puanlarının empatik eğilim ve öznel iyi oluş puanları arasında istatistiksel olarak anlamlı ilişkilerin olduğu görülmektedir. Bu sonuçlardan hareketle, öğretmen adaylarının kültürlerarası duyarlılık puanlarını yordamadaki katkılarını incelemek üzere, kültürlerarası duyarlılık puanları ile anlamlı ilişkilere sahip olduğu bulunan değiş̧kenler, çoklu regresyon analizine dahil edilmiş ve sonuçlar Tablo 2'de verilmiştir.

Tablo 2.

Öğretmen Adaylarının Empatik Eğilim ve Öznel İyi Oluş Puanlarının Kültürlerarası Duyarlılık Puanlarını Yordayıp Yordamadığına ilişkin Çoklu Regresyon Analizi Sonuçları

\begin{tabular}{llllll}
\hline \multirow{2}{*}{ Değişkenler } & \multicolumn{2}{l}{ Kültürlerarası Duyarlılık } & \multicolumn{2}{l}{} \\
& $\mathrm{B}$ & $\mathrm{SH}$ & $\mathrm{B}$ & $\mathrm{t}$ & $\mathrm{p}$ \\
\hline Sabit & 58.42 & 4.94 & - & 11.83 & 0.00 \\
Empatik Eğilim & .47 & .07 & .37 & 6.54 & 0.00 \\
Öznel İyi Oluş & .64 & .27 & .13 & 2.36 & 0.02 \\
$\mathrm{R}=.46, R^{2}=.21$ & & & & \\
$\mathrm{~F}_{(2-352)=46.26,} \mathrm{p}=0.00 * *$ & & & & \\
$* * \mathrm{p}<.01$ & &
\end{tabular}

Tablo 2'ye bakıldığında, öğretmen adaylarının kültürlerarası duyarlılık puanları ile empatik eğilim ve öznel iyi oluş puanları arasında pozitif yönde anlamlı ilişkiler $\left(\mathrm{R}=.46, R^{2}=.21\right)$ olduğu ve empatik eğilim ve öznel iyi oluş puanlarının birlikte kültürlerarası duyarlılık puanlarına ilişkin varyansın \% 21'ini açıklayarak kültürlerarası duyarlılık puanlarının anlamlı birer yordayıcıları olduğu görülmüştür.

Standardize edilmiş regresyon katsayılarına $(\beta)$ göre, yordayıcı değişkenlerin kültürlerarası duyarlılık puanlarındaki göreli önem sırası; empatik eğilim ve öznel iyi oluş biçimindedir. Regresyon katsayılarının anlamlılığına ilişkin t-testi sonuçları incelendiğinde empatik eğilim ve öznel iyi oluş puanlarının, kültürlerarası duyarlılık puanları üzerinde anlamlı yordayıcılar olduğu görülmektedir.

Öğretmen adaylarının kültürrlerarası duyarlılık puanlarının cinsiyet değişkenine göre farklılaşıp farklılaşmadığına ilişkin bulgular

Öğretmen adaylarının kültürlerarası duyarlılık puanlarının cinsiyet değişkenine göre farklılaşıp farklılaşmadığına ilişkin “Bağımsız Gruplar için t-testi” sonuçları Tablo 3’te verilmiştir.

Tablo 3.

Öğretmen Adaylarının Cinsiyet Değişkenine Göre Kültürlerarası Duyarlılık Puanlarının Ortalama, Standart Sapma ve "t" Değerleri

\begin{tabular}{llllll}
\hline & Cinsiyet & $\mathrm{N}$ & $\overline{\mathrm{X}}$ & $\mathrm{S}$ & $\mathrm{t}$ \\
\cline { 2 - 6 } Kültürleraras1 & Kadın & 253 & 91.28 & 10.13 & \multirow{2}{*}{1.80} \\
Duyarl11kk & Erkek & 102 & 89.11 & 10.64 & \\
\hline
\end{tabular}
$* \mathrm{p}<.05$

Tablo 3 incelendiğinde, öğretmen adaylarının kültürlerarası duyarlılık puanları arasında $\left[\mathrm{t}_{(353)}=1.80 ; \mathrm{p}>.05\right]$ cinsiyet değişkeni açısından herhangi bir anlamlı farklılık görülmemiştir.

Öğretmen adaylarının kültürlerarası duyarlıık puanlarının öğrenim gördükleri programlarına göre farklılaşıp farklılaşmadığına ilişkin bulgular

Öğretmen adaylarının kültürlerarası duyarlılık puanlarının öğrenim gördükleri programlarına göre farklılaşıp farklılaşmadığına ilişkin tek yönlü varyans analizi (ANOVA) sonuçları Tablo 4 'te verilmiş̧ir. 
Öğretmen Adaylarının Kültürlerarası Duyarlılıklarının Empatik Eğilim, Öznel İyi Oluş ve SosyoDemografik Değişkenler Açısından İncelenmesi

Tablo 4.

Öğretmen Adaylarının Kültürlerarası Duyarlılık Puanlarının Öğrenim Gördükleri Programlarına Göre Göre Farklılaşıp Farklılaşmadığına Yönelik Tek Yönlü Varyans Analizi (ANOVA) Testi Sonuçları

\begin{tabular}{lllllllll}
\hline $\begin{array}{l}\text { Bağıml1 } \\
\text { Değișken }\end{array}$ & $\begin{array}{l}\text { Öğrenim } \\
\text { Gördükleri } \\
\text { Program }\end{array}$ & $\mathrm{N}$ & $\overline{\mathrm{X}}$ & $\mathrm{S}$ & $\mathrm{F}$ & $\mathrm{p}$ & $\begin{array}{l}\text { Anlamlı } \\
\text { Fark }\end{array}$ & $\eta_{2}$ \\
& FBÖ & 46 & 88.41 & 1.68 & & & & \\
& MÖ & 53 & 87.71 & 8.80 & & & IÖ & \\
& İ̈ & 41 & 96.83 & 9.56 & & & $>$ & \\
Kültürleraras1 & TÖ & 53 & 90.70 & 10.83 & 4.33 & $.000^{*}$ & FBÖ, & MÖ, \\
Duyarl1lık & SÖ & 40 & 93.23 & 9.01 & & & OÖÖ2, & \\
& OÖÖ1 & 31 & 92.68 & 13.50 & & & PDR & \\
& OÖÖ2 & 31 & 87.48 & 9.75 & & & & \\
& PDR & 60 & 89.60 & 7.70 & & & & \\
\hline
\end{tabular}

$\mathrm{p}<.05$

Not: FBÖ: Fen bilgisi öğretmenliği, MÖ: Matematik öğretmenliği, İÖ: İngilizce öğretmenliği, TÖ: Türkçe öğretmenliği, SÖ: Sınıf öğretmenliği, OÖÖ1: Okul öncesi öğretmenliği birinci öğretim, OÖÖ2: Okul öncesi öğretmenliği ikinci ögretim, PDR: Psikolojik danışmanlık ve rehberlik

Tablo 4 incelendiğinde, öğretmen adaylarının öğrenim gördükleri program değișkenine göre gerçekleştirilen tek yönlü ANOVA sonuçlarına göre, kültürlerarası duyarlılık $\left[\mathrm{F}_{(7-347)}=4.33\right.$; $\mathrm{p}<.05, \eta 2=.08$ ] puanları arasındaki farkın anlamlı olduğu görülmektedir. Gruplar arasında gözlenen bu farkın kaynağını belirlemek için verilere post-hoc testlerden Scheffe uygulanmıştır. Öğretmen adaylarının öğrenim gördükleri program değişkenine göre, İngilizce öğretmenlerinin kültürlerarası duyarlılık puan ortalamalarının FBÖ, MÖ, OÖÖ2 ve PDR puan ortalamalarından anlamlı düzeyde yüksek olduğu görülmektedir. Buna ek olarak, elde edilen eta kare değerlerine göre öğrenim gördükleri program değişkeninin kültürleraras1 duyarlılık $(\eta 2=.08)$ puan ortalamalarına etkisi orta düzeyde bulunmuştur.

Öğretmen adaylarının kültürlerarası duyarlılık puanlarının yurtdışı deneyimlerine göre farklılaşıp farklılaşmadığına ilişkin bulgular

Öğretmen adaylarının kültürlerarası duyarlılık puanlarının yurtdışı deneyimlerine göre farklılaşıp farklılaşmadığına ilişkin tek yönlü varyans analizi (ANOVA) sonuçları Tablo 5'te verilmiştir.

Tablo 5.

Öğretmen Adaylarının Kültürlerarası Duyarlılık Puanlarının Yurtdışı Deneyimlerine Göre Farklılaşıp Farklılaşmadığına Yönelik Tek Yönlü Varyans Analizi (ANOVA) Testi Sonuçları

\begin{tabular}{lllllllll}
\hline Bağımlı & \multirow{2}{*}{ Yurtdışı Deneyimi } & $\mathrm{N}$ & $\overline{\mathrm{X}}$ & $\mathrm{S}$ & $\mathrm{F}$ & $\mathrm{p}$ & $\begin{array}{l}\text { Anlamlı } \\
\text { Fark }\end{array}$ & $\eta_{2}$ \\
\hline & DY & 301 & 89.85 & 10.27 & & & $12 \mathrm{AK}$, & \\
Kültürleraras1 & 30GK & 17 & 97.24 & 8.99 & & & $30 \mathrm{GK}$ & \\
Duyarlıl1k & 12AK & 21 & 98.38 & 8.06 & 7.42 & $.000^{*}$ & $>$ & .08 \\
& 1YF & 16 & 88.69 & 8.83 & & & DY, & \\
& & & & & & & 1YF & \\
\hline
\end{tabular}

$\mathrm{p}<.05$

Not: DY: Deneyim yok, 30 GK: 30 güne kadar, 12 AK: 12 aya kadar, 1YF:1 yıldan fazla

Tablo 5 incelendiğinde, öğretmen adaylarının yurtdışı deneyim değişkenine göre gerçekleştirilen tek yönlü ANOVA sonuçlarına göre, kültürlerarası duyarlılık $\left[\mathrm{F}_{(3-351)}=4.33\right.$; $\mathrm{p}<.05, \eta 2=.08]$ puanları arasındaki farkın anlamlı olduğu görülmektedir. Gruplar arasında gözlenen bu farkın kaynağını belirlemek için verilere post-hoc testlerden Scheffe uygulanmıştır. Öğretmen adaylarının yurtdışı deneyim değişkenine göre, yurtdışı deneyimi 12AK ve 30 GK olan 
öğretmen adaylarının kültürlerarası duyarlılık puan ortalamalarının DY ve 1YF puan ortalamalarından anlamlı düzeyde yüksek olduğu görülmektedir. Buna ek olarak, elde edilen eta kare değerlerine göre öğrenim gördükleri program değişkeninin kültürlerarası duyarlılık $(\eta 2=.06)$ puan ortalamalarına etkisi küçük düzeyde bulunmuştur.

Öğretmen adaylarının kültürlerarası duyarlılık puanlarının algılanan yabancı dil düzeyine göre farklılaşıp farklılaşmadığına ilişkin bulgular

Öğretmen adaylarının kültürlerarası duyarlılık puanlarının algılanan yabancı dil düzeyine göre farklılaşıp farklılaşmadığına ilişkin tek yönlü varyans analizi (ANOVA) sonuçları Tablo 6'da verilmiştir.

Tablo 6.

Öğretmen Adaylarının Kültürlerarası Duyarlılık Puanlarının Algılanan Yabancı Dil Düzeyine Göre Farklılaşıp Farklılaşmadığına Yönelik Tek Yönlü Varyans Analizi (ANOVA) Testi Sonuçları

\begin{tabular}{lllllllll}
\hline $\begin{array}{l}\text { Bağımlı } \\
\text { Değişken }\end{array}$ & $\begin{array}{l}\text { Algılanan Yabanc1 } \\
\text { Dil Düzeyi }\end{array}$ & $\mathrm{N}$ & $\overline{\mathrm{X}}$ & $\mathrm{S}$ & $\mathrm{F}$ & $\mathrm{p}$ & $\begin{array}{l}\text { Anlamlı } \\
\text { Fark }\end{array}$ & $\eta_{2}$ \\
\hline & Yok & 81 & 88.25 & 9.11 & & & İleri & \\
Kültürlerarası & Başlangıç & 147 & 89.71 & 10.45 & & & \\
Duyarlılık & Orta & 85 & 92.27 & 10.14 & 5.71 & $.000^{*}$ & Y & .05 \\
& İleri & 42 & 95.36 & 10.68 & & & Yok, & Başlangıç \\
& & & & & & & \\
\hline
\end{tabular}

$\mathrm{p}<.05$

Tablo 6 incelendiğinde, öğretmen adaylarının algılanan yabancı dil düzeyi değişkenine göre gerçekleştirilen tek yönlü ANOVA sonuçlarına göre, kültürlerarası duyarlılık $\left[\mathrm{F}_{(3-351)}=5.71\right.$; $\mathrm{p}<.05, \eta 2=.05]$ puanları arasındaki farkın anlamlı olduğu görülmektedir. Gruplar arasında gözlenen bu farkın kaynağını belirlemek için verilere post-hoc testlerden Scheffe uygulanmıştır. Öğretmen adaylarının algılanan yabancı dil düzeyi ileri olanların, kültürlerarası duyarlılık puan ortalamalarının yok ve başlangıç düzeyinde algılayanların puan ortalamalarından anlamlı düzeyde yüksek olduğu görülmektedir. Buna ek olarak, elde edilen eta kare değerlerine göre algılanan yabancı dil düzeyi değişkeninin kültürlerarası duyarlılık $(\eta 2=.05)$ puan ortalamalarına etkisi küçük düzeyde bulunmuştur.

Öğretmen adaylarının kültürlerarası duyarlılık puanlarının farklı ülke ya da kültürlerden tanıdıklara sahip olmalarına göre farklılaşıp farklılaşmadığına ilişkin bulgular

Öğretmen adaylarının kültürlerarası duyarlılık puanlarının farklı ülke ya da kültürlerden tanıdıklara sahip olmalarına göre farklılaşıp farklılaşmadığına ilişkin t testi sonuçları Tablo 7'de verilmiştir.

Tablo 7.

Öğretmen Adaylarının Kültürlerarası Duyarlılık Puanlarının Farklı Ülke ya da Kültürlerden Tanıdıklara Sahip Olmalarına Göre Farklılaşıp Farklılaşmadığına Yönelik T Testi Sonuçları

\begin{tabular}{|c|c|c|c|c|c|c|c|c|}
\hline $\begin{array}{l}\text { Bağımlı } \\
\text { Değişken }\end{array}$ & $\begin{array}{l}\text { FÜ ya da } \\
\text { KTSO }\end{array}$ & $\mathrm{N}$ & $\overline{\mathrm{X}}$ & S & $\mathrm{T}$ & $\mathrm{P}$ & $\begin{array}{l}\text { Anlamlı } \\
\text { Fark }\end{array}$ & $\eta_{2}$ \\
\hline Kültürlerarası & Evet & 246 & 92.28 & 10.19 & & & Evet $>$ Havır & \\
\hline Duyarlıl1k & Hayır & 109 & 86.97 & 9.71 & 4.51 & $.000^{*}$ & Evet $>$ Hayır & .06 \\
\hline
\end{tabular}

Tablo 7 incelendiğinde, öğretmen adaylarının farklı ülke ya da kültürlerden tanıdıklara sahip olma değişkenine göre gerçekleştirilen t testi sonuçlarına göre, kültürlerarası duyarlılık $\left[\mathrm{t}_{(353)}=4.57 ; \mathrm{p}<.05, \eta 2=.06\right]$ puanları arasındaki farkın anlamlı olduğu görülmektedir. Öğretmen 
adayları arasında farklı ülke ya da kültürlerden tanıdıklara sahip olanların kültürlerarası duyarlılık puan ortalamalarının olmayanların puan ortalamalarından anlamlı düzeyde yüksek olduğu görülmektedir. Buna ek olarak, elde edilen eta kare değerlerine göre farklı ülke ya da kültürlerden tanıdıklara sahip olma değişkeninin kültürlerarası duyarlılık $(\eta 2=.06)$ puan ortalamalarına etkisi küçük düzeyde bulunmuştur.

Öğretmen adaylarının kültürlerarası duyarlılık puanlarının farklı ülke ya da kültürlerden yakın arkadaşlara sahip olmalarına göre farklılaşıp farklılaşmadığına iliş̧in bulgular

Öğretmen adaylarının kültürlerarası duyarlılık puanlarının farklı ülke ya da kültürlerden yakın arkadaşlara sahip olmalarına göre farklılaşıp farklılaşmadığına ilişkin t testi sonuçları Tablo 8'de verilmişsir.

Tablo 8.

Öğretmen Adaylarının Kültürlerarası Duyarlılık Puanlarının Farklı Ülke ya da Kültürlerden Yakın Arkadaşlara Sahip Olmalarına Göre Farklılaşıp Farklılaşmadığına Yönelik T Testi Sonuçları

\begin{tabular}{|c|c|c|c|c|c|c|c|c|}
\hline BağımlıDeğişken & $\begin{array}{l}\text { FÜ ya da } \\
\text { KYASO }\end{array}$ & $\mathrm{N}$ & $\overline{\mathrm{X}}$ & S & $\mathrm{T}$ & $\mathrm{p}$ & $\begin{array}{l}\text { Anlamlı } \\
\text { Fark }\end{array}$ & $\eta_{2}$ \\
\hline Kültürleraras1 & Evet & 166 & 92.34 & 10.59 & 200 & $004 *$ & & 02 \\
\hline Duyarlılık & Hayır & 189 & 89.17 & 9.86 & 2.92 & $.004^{*}$ & Evet $>$ Hayir & .02 \\
\hline
\end{tabular}

Tablo 8 incelendiğinde, öğretmen adaylarının farklı ülke ya da kültürlerden yakın arkadaşlara sahip olma değişkenine göre gerçekleştirilen t testi sonuçlarına göre, kültürlerarası duyarl11ık $\left[\mathrm{t}_{(353)}=2.92 ; \mathrm{p}<.05, \eta 2=.02\right]$ puanları arasındaki farkın anlamlı olduğu görülmektedir. Öğretmen adayları arasında farklı ülke ya da kültürlerden yakın arkadaşlara sahip olanların kültürlerarası duyarlılık puan ortalamalarının olmayanların puan ortalamalarından anlamlı düzeyde yüksek olduğu görülmektedir. Buna ek olarak, elde edilen eta kare değerlerine göre farklı ülke ya da kültürlerden yakın arkadaşlara sahip olma değişkeninin kültürlerarası duyarlılık ( $\eta 2=$ .02) puan ortalamalarına etkisi küçük düzeyde bulunmuştur.

\section{Tartışma, Sonuç ve Öneriler}

Öğretmen adaylarının empatik eğilim ve öznel iyi oluş puanlarının kültürlerarası duyarlılık puanlarını yordamadaki katkılarını inceleyerek, kültürlerarası duyarlılık puanlarının cinsiyet, öğrenim gördükleri program, yurtdışı deneyimi, algılanan yabancı dil düzeyi, farklı ülke ya da kültürlerden tanıdıklara ve yakın arkadaşlara sahip olma sosyo-demografik değişkenleri açısından farklılaşıp farklılaşmadığını incelenmesinin amaçlandığı bu araştırmada kültürlerarası duyarlılık, empatik eğilim ve öznel iyi oluş arasında pozitif yönlü anlamlı ilişkiler tespit edilmiştir. Ayrıca en fazla empatik eğilim daha sonra öznel iyi oluşun, kültürlerarası duyarlılık puanlarının anlamlı yordayıcıları olduğu görülmüştür. Empati, kültürlerarası duyarlılığın yordayıcısı olarak alanyazınında, lisans ve lisansüstü öğrencilerde (Abasl1, 2018), psikolojik danışman adaylarında (Aydın ve Şahin, 2017), hemşire adaylarında (Egelioğlu Çetişli ve diğerleri, 2016) ve 10-13 yaş İspanyol öğrencilerinde (Micó-Cebrián, Cava ve Buelga, 2019) gerçekleştirilen çalışmalar ile tutarlılık gösterdiği söylenebilir. Kültürlerarası duyarlılık geliştirebilen bireyin sahip olması gereken özelliklerden birisi olan empati, kültürlerarası duyarlılık kavramında merkezi bir role sahiptir ve kültürlerarası iletişimde yetkin olmasını sağlayan bir özelliktir (Chen ve Starosta, 2000). Kültürlerarası duyarlılık, empatinin aracılığı ile farklı kültürel özelliklere sahip kişilerin dünyasına girebilmektedir ve yeni durumları, farklı rollerdeki kişileri anlaması kolaylaştırmaktadır (Chen ve Starosta, 1996). Empatik bireyler, farklı kültürel özelliklere sahip gruplara ait bireylerin bakış açılarını ve duygularını daha fazla anlama ve değer verme eğilimindedir. "Diğerlerini" daha iyi anlama ve duygularını paylaşma, sonuç olarak daha az önyargı ve çatışmaya götürürken diğer yandan sosyal etkileşimin artmasına neden olabilmektedir 
(Deitch Feshbach ve Feshbach, 2009). Mevcut araştırmada kültürlerarası duyarlılığ1 yordamasından haraketle, empatinin; değerleri, görüşleri, dilleri, diyalektleri, davranışları kısacası kültürel özellikleri farklı olan bireyleri anlamamıza yardımcı olan ve kültürlerarası duyarlılığ1 etkileyen önemli bir faktör olduğu söylenebilir.

Benzer biçimde, bu araştırmada öğretmen adaylarının öznel iyi oluş puanlarının, kültürlerarası duyarlılık puanlarının anlamlı bir yordayıcısı olduğu yönündeki mevcut araştırma bulgusuna benzer olarak, Öğ̈̈t (2017), ülkemizde 17-70 yaş arası katılımcılar ile gerçekleştirdiği araştırmasında kültürlerarası duyarlılığın hem öznel iyi oluşun bilişsel boyutunu temsil eden yaşam doyumu hem de mutluluk düzeyi değişkenleri ile pozitif yönde anlamlı ilişkiler olduğunu bulmuştur. Bir diğer benzerlik gösteren çalışma ise İspanyol 10-13 yaşındaki öğrenciler ile gerçekleştirilmiştir. Bu araştırmada empati ve yaşam doyumu yükseldikçe kültürlerarası duyarlılığın arttığ 1 sonucuna ulaşılmıştır (Micó-Cebrián ve Cava, 2014). Öznel iyi oluşu yüksek bireyler diğer bireylere göre daha fazla güven duyan, işbirlikçi ve uzlaşma yanlısı tutumlara sahip olma ve göçmenler ile etnik kökeni farklı gruplara daha fazla tolerans gösterme eğilimindedir (Diener ve Tov, 2007; Tov ve Diener, 2008).

Diğer yandan, bu araştırma kapsamında öğretmen adaylarının kültürlerarası duyarlılık puanlarının bazı sosyo-demografik değişkenler (cinsiyet, öğrenim gördükleri program, yurtdış1 deneyimi, algılanan yabancı dil düzeyi, farklı ülke ya da kültürlerden tanıdıklara ve yakın arkadaşlara sahip olma) açısından farklılaşıp farklılaşmadığ 1 incelenmiştir. Öğretmen adaylarının kültürlerarası duyarlılık puanları arasında cinsiyet değişkeni açısından kadın öğretmen adaylarının puan ortalamaları erkeklerden az bir fark ile yüksek olsa da herhangi bir anlamlı farklılık tespit edilmemiştir. Alanyazınında, kadın ilkokul ve ortaokul öğrencilerinin lehine çalışmalar bulunsa da (Holme, Petri ve Kirsi, 2006; Micó-Cebrián ve Cava, 2014) mevcut araştırmanın bulgusunda öğretmen adayı ve öğretmenler (Akın, 2016; Bayles, 2009; Erdoğan, 2018; Güner ve Levent, 2018; Spinthourakis, Karatzia-Stavlioti ve Roussakis, 2009; Üstün, 2011; Yılmaz ve Göçen, 2013), üniversite hazırlık sınıfında öğrenim görmekte olan öğrenciler (Çiloğlan ve Bardakçı, 2019) ve farklı bölümlerden oluşan lisans öğrencileri (Abaslı ve Polat, 2019; Bulduk, Usta ve Dinçer, 2017; Gordon ve Mwavita, 2018) ile gerçekleştirilen çalışmalarla benzerlik göstererek cinsiyet açısından farklılaşma tespit edilmemiştir.

Öğretmen adaylarının öğrenim gördükleri program değişkenine göre, İngilizce öğretmenliği öğrencilerinin kültürlerarası duyarlılık puan ortalamalarının Fen Bilgisi Öğretmenliği, Matematik Öğretmenliği, Okul Öncesi Öğretmenliği İkinci Öğretim ve Psikolojik Danışmanlık ve Rehberlik puan ortalamalarından anlamlı düzeyde yüksek olduğu bulgulanmıştır. Araştırma grubunda yer alan diğer bölümlerden İngilizce Öğretmenliği bölümü öğrencilerinin lehine anlamlı biçimde farklılaştığı yönündeki bulguların, alanyazında öğretmen adaylarıyla gerçekleştirilen benzer çalışmalar ile tutarlı olduğu görülmüştür (Demir ve Üstün, 2017; Üstün, 2011). Güler (2012), yeni bir dil öğrenen öğrencilerin yabancı dilin yanı sıra yeni bir kültür, coğrafya ve dünya ile tanıştı̆̆ını ifade etmiştir. Bir yabancı dili iyi derecede öğrenmesi ve bu yabancı dili ve içindeki kültür ögesini de öğretebilme yeterliliğine sahip olması beklenen İngilizce öğretmenlerinin, eğitimi sırasında kültürlerarası yeterliliklerine olumlu katkı sağlayacak derslerin içeriğinde edebiyat ve kültürün yanı sıra genel olarak tartışma ve iletişim becerilerini geliştirecek ders etkinlik ve içerikleri bulunmaktadır. Ayrıca, yararlandıkları kitaplarda hedef dilin konuşulduğu ülke ve diğer yabanc1 ülkelere ait kültürel bilgiler bulunduğundan İngilizce öğretmenliği adaylarının diğer kültürlere karşı içgörü ve duyarlılık kazanabilmesinin kolaylaşabileceği söylenebilir. Öte yandan, çalışma grubuna dahil edilen Psikolojik Danışmanlık ve Rehberlik öğrencilerinin kültürlerarası duyarlılık puan ortalamalarının diğer bölümlerden farklılaşmaması çarpıcı ve beklenmedik bir bulgu olarak değerlendirilebilir. Çünkü psikolojik danışmanların etkili uygulamalarda bulunabilmesi için kültürel farklılıklara yönelik farkındalık ve danışanların ihtiyaçlarına duyarlı olma becerisi çok fazla önem taşımaktadır (Burnett, Hamel ve Long, 2004; Sue ve Sue, 2012).

Benzer biçimde, öğretmen adaylarının algılanan yabancı dil düzeyi ileri düzeyde olanların kültürlerarası duyarlılık puan ortalamalarının yabancı dili olmayan ve başlangıç düzeyinde olanların puan ortalamalarından anlamlı düzeyde yüksek olduğu bulgulanmıştır. $\mathrm{Bu}$ 
sonuç yabancı dil bilme değişkeni açısından üniversite öğrencilerinde (Bekiroğlu ve Balcı, 2014; Bulduk, Usta ve Dinçer, 2017; Meydanlığlu, Arıkan ve Gözüm, 2015; Öğüt ve Olkun, 2018) tutarlılık göstermektedir. Çiloğlan ve Bardakçı (2019) üniversite hazırlık sınıfı öğrencileri ile gerçekleştirdiği çalışmasında kültürlerarası duyarlılık ve yabancı dil olarak İngilizce dil başarı seviyesine (A2, B1 ve B2) göre farklılaşıp farklılaşmadığını incelediği çalışmasında mevcut çalışma ile benzer şekilde ileri dil seviyesi lehine kültürlerarası duyarlılık puanında farklılaşma raporlamıştır. Dil, kişilerarası iletişim ve sosyal ilişkilerin düzenlenmesinde aracı bir unsurdur (Köse, Tetik ve Ercan, 2001). Bennett, Bennett ve Allen (2003) dil yeterliliği ve kültürlerarası duyarlılık arasındaki tipik uyumu kültürlerarası duyarlılık modeli (Bennett, 1998) açısından değerlendirmiştir. Yabanc1 dil düzeyi yüksek bireylerin kültürel farklılıklardan zevk aldığı, davranışlarını farklı kültürel ortamlara uyum sağlayacak şekilde değiştirebildiği ve bir davranışı değerlendirirken geniş bir kültürel çerçeveden bakabildiği etnik göreceli kültürel gelişim dönemine daha eğilimli bulmuştur. Diğer yandan, yabancı dil seviyesi daha düşük düzeyde olan bireylerin, çoğu zaman farkında olmadan diğer insanları kendi değerleriyle yargıladığı, reddetme, savunma ve küçümseme evrelerinin yer aldığı etnik merkezci döneme daha yakın olabileceğini savunmuştur. Buradan haraketle, yabancı dil düzeyi artıkça öğretmen adaylarının kültürlerarası duyarlılık düzeyinin de arttığı söylenebilir.

Öğretmen adaylarından yurtdışı deneyimi otuz gün ile on iki aya kadar olanların kültürlerarası duyarlılık puan ortalamalarının herhangi bir deneyimi olmayanlar ile bir yıl ve üzeri deneyimi olan öğretmen adaylarının puan ortalamalarından anlamlı düzeyde yüksek olduğu yönündeki sonuçların alanyazında öğretmen adayları (Demir ve Üstün, 2017; Üstün, 2011), öğretmenler (Westrick, Celeste ve Yuen, 2007) üzerinde gerçekleştirilen araştırma sonuçlarıyla benzerlik göstermektedir. Bu durumda başka bir ülkede farklı kültürleri ve kendi kültürünü de yurtdışında deneyimleme imkanının bireyin farklı bakış açıları geliştirmesine yardımcı olabileceği böylelikle de kültüre duyarlılığının gelişmesine katkı sağlayabileceği düşünülebilir. Öte yandan yurtdışında bulunup bulunmama durumu ülkemizde İletişim Fakültesi öğrencilerinde (Bekiroğlu ve Balc1, 2014) ve Amerika'daki üniversite öğrencilerinde (Gordon ve Mwavita, 2018) altı ay ve üzeri yurtdışı deneyimi olanların hiç olmayanlara göre kültürlerarası duyarlılık puanında anlamlı farklılık yaratmadığı görülmüsstür. Mevcut araştırmada öğretmen adaylarında kültürlerarası duyarlılığın bir yıl ve üzeri yurtdışında bulunma deneyimine sahip olma açısından farklılaşmamasının sonucunun bu araştırma sonuçlarıyla tutarlılık gösterdiği düşünülebilir. Her ne kadar araştırılmak istenen yurtdışı deneyimi değişkeninin süresi bu çalışma kapsamında en fazla bir yıl ve üzeri şeklinde sınırlandırılmış olsa da Helmer (2007) öğretmenlerin uzun süreli yurtdışı deneyimin (10 yıl) benzerlik gösterebilecek şekilde kültürlerarası duyarlılık ile negatif ilişkili olduğunu belirtmiştir. Yurtdışı deneyiminde vurgulanması gereken asıl nokta yabancı bir kültürde yaşamış olmanın her zaman kültürlerarası duyarlılığa olumlu katkı sağlayabileceği anlamı taşımadığı yönündedir. Bireyin yurtdışında deneyimlediği yaşantısı ve bu yaşantılara bağlı olarak gerçekleştirdiği algı, değerlendirme ve duygusal tepkilerin bireysellik ve subjektiflik taşımasından ötürü diğer kültürlere karşı duygu, düşünce ve davranışlarını olumlu veya olumsuz yönde etkileyebileceğinin göz ardı edilmemesi gerektiğinin söylenebileceği düşünülmektedir. Anderson, Lawton, Rexeisen ve Hubbard (2006) iyi planlanmış kısa süreli yurtdışı programlarının da kültürlerarası duyarlılığı geliştirebileceğine vurguda bulunmuştur. Bir başka deyişle, yurtdışında geçirilen zamanın artmasının her zaman bireylerin kültürlerarası duyarlılığı ile doğrudan olumlu ilişkili geliştirmeyebileceği söylenebilir.

Son olarak öğretmen adayları arasında farklı ülke ya da kültürlerden "tanıdıklara" ve yine farklı ülke ya da kültürlerden "yakın arkadaşlara" sahip olanların kültürlerarası duyarlılık puan ortalamalarının olmayanların puan ortalamalarından anlamlı düzeyde yüksek olduğu yönündeki sonuçların, farklı kültürlerden kişiler ile etkileşimde bulunan aday psikolojik danışmanlar (Tuncel ve Arıcıoğlu, 2018) ve lisans öğrencilerinde (Bulduk, Usta ve Dinçer, 2017; Korkmaz-Aslan, Kartal, Turan, Taşdemir-Yiğitoğlu ve Kayan, 2019); farklı ülkelerden arkadaşa sahip olan üniversite öğrencileri (Öğ̈̈t ve Olkun, 2018) ve öğretmen adaylarında (Akın, 2016; Demir ve Üstün, 2017; Üstün, 2011) daha yüksek kültürlerarası duyarlılık puanlarına işaret ettikleri araştırma sonuçlarıyla paralellik göstermektedir. Bireyler tanımadıkları kişileri tehlikeli 
algılayabilmekteyken tanımaya başladıklarında rahatlama duygusuyla o kişilere olumlu hissetmeleri kolaylaşmaktadır. Farklı insanları tanımada görme sıklığı ile o kişilere ait bilgilerin artması, onlara nasıl davranılacağını daha başarılı bir şekilde kestirme ve tanıdık olan kişiler ile daha rahat hissetmeye neden olmaktadır (Taylor, Peplau ve Sears, 2012, s. 248). Aynı zamanda bireylerin yabancılar ile geçirdikleri zaman artıkça yabancılar ile etkileşimde bulunmaya olan istekleri de artmaktadır (Ward, 2001). Yani bireylerin çeşitli kültürler ile tanıdıklık ve yakın arkadaşlık aracılığıyla etkileşimde bulunma deneyimlerinin kültürlerarası duyarlılığı olumlu yönde etkilediği söylenebilir.

Araştırmanın bulgularına göre empatik eğilim ve öznel iyi oluş puanlarının kültürlerarası duyarlılığın yordaycıları olarak bulunması sonuçları 1şı̆̆ında, öğretmen adaylarının ve farklı bölümlerden üniversite öğrencilerinin empatik eğilim ve iyi oluşlarını artırmaya yönelik üniversite mediko-sosyal birimleri, psikolojik danışma birimlerince bireysel ve grup çalışmaları yapılmasının oldukça önemli olduğu düşünülmektedir. Bunların yanı sıra, sahada çalışmakta olan öğretmenler için de Milli Eğitim Bakanlığı tarafından empatik eğilim ve öznel iyi oluş temelinde öğretmenlerin kültürlerarası duyarlılığını artırmaya yönelik hizmet içi eğitimler verilmesi yararlı olacaktır. Diğer yandan, mevcut araştırma bulgusu doğrultusunda PDR öğrencilerinin özellikle Psikolojik Danışma ve Rehberlik lisans programlarına "Kültüre Duyarlı Psikolojik Danışma" dersinin dahil edilmesinin önemli olduğu düşünülmektedir. Diğer yandan, Erasmus gibi yurtdış1 öğrenci değişim ve staj programlarına dahil olacak öğretmen adaylarına ve üniversite öğrencilerine yönelik kültürlerarası duyarlılık temelli eğitim, seminer gibi yapılacak hazırlık çalışmalarının kültürlerarası duyarlılığın artmasında etkili olabileceği söylenebilir. Ayrıca üniversitelerarası anlaşmaların sınırlılıkları ve öğrencilerin ekonomik ulaşılabilirlikleri göz önünde bulundurulduğunda kültürlerarası etkileşimin sadece yurtdışı olarak düşünülmemesi, bölgesel ve ulusal kampüs etkinlikleri aracılığıyla kültürel çeşitliliklere yönelik etkinliklerin düzenli olarak üniversite kampüslerinde yapılmasının yararlı olacağı düşünülmektedir.

Diğer yandan, mevcut araştırmada bazı sinırlılıklar söz konusudur. Bunlardan bir tanesi empatinin duyuşsal ve bilişsel gibi ayırt edilebilecek şekilde desenlenmeyerek empatik eğilim üzerinden değerlendirilmiş olmasıdır. Gelecekte yapılacak çalışmalarda araştırmacıların empatiyi çok yönlü değerlendirmesi durumunda kültürlerarası duyarlılığın açılanması sürecine katkılar sağlayabileceği düşünülmektedir. Dil seviyesinin algılanan yani öğretmen adaylarının öz bildirimleri üzerinden kategorik olarak ve bireylerin Türkçe dışında başka dillerde anadilleri olup olmaması durumu ayırt edilmeden doğrudan yabanc1 dil olarak sorgulanmış olması da araştırmanın bir diğer sınırlılı̆̆ıdır. Gelecekteki çalışmalarda bireylerin birden fazla anadile sahip olup olmaması ve sahip olduğu yabancı dil sayısı açısından ayırt edilmesi kültürlerarası duyarlılık açısından daha derin bilgiler sunabilecektir. Araştırmanın bir diğer sınırlılığı öğretmen adaylarının yurt dışında bulunma amacı bilinmeden analize alınması sonucu çok yönlü bilgiye ulaşılamamış olunmasıdır. Bu nedenle yurtdışında bulunma amaçlarının seyahat, tanıdık ziyareti, akademik eğitim, dil eğitimi, staj vb. yönlerden sorgulanmasının kültürlerarası duyarlılık puanları üzerindeki etki gücü hakkında daha detaylı bilgiler sunabilecektir. Benzer şekilde farklı ülke ya da kültürlerden "tanıdıklara" ve farklı ülke ya da kültürlerden "yakın arkadaşlara" sahip olup olmama sosyo-demografik değişkenleri yabancılar ile etkileşim açısından değerlendirilirken kendi ülkesinde, yabancı bir ülkede ve kitle iletişim araçları aracılığı olup olmaması sorgulanmamıştır. $\mathrm{Bu}$ kategorilerin dahil edilmesi ve kitle iletişim araçların türünün de sorgulanması kültürlerarası duyarlılık hakkında alanyazına yeni bilgiler sunabilecektir.

\section{Kaynaklar}

Abaslı, K. (2018). Kültürlerarası duyarlılık ve empati arasındaki ilişkilerin Türk ve uluslararası öğrenci görüşlerine göre incelenmesi. TÜBAV Bilim Dergisi, 11(2), 11-23.

Abaslı, K. ve Polat, Ş. (2019). Öğrencilerin kültürlerarası duyarlılık ve kültürel zekaya ilişkin görüşlerinin incelenmesi. Anemon Muş Alparslan Üniversitesi Sosyal Bilimler Dergisi, 7(1), 193-202.

Akın, E. (2016). Türkçe öğretmen adaylarının kültürlerarası duyarlılıklarının çeşitli değişkenler açısından incelenmesi. Turkish Studies, 11(3), 29-42. 
Anderson, P., Lawton, L., Rexeisen, R. ve Hubbard, A. (2006). Short-term study abroad and intercultural sensitivity: A pilot study. International Journal of Intercultural Relations, 30, 457-469.

Argyle, M., Martin, M. ve Crossland, J. (1989). Happiness as a function of personality and social encounters. J. P. Forgas ve J. M. Innes (Yay. haz.), Recent Advances in Social Psychology: an International Perspective, içinde (ss. 189-203). Amsterdam: North Holland, Elsevier Science.

Aspy, D. N. (1975). Helping teachers discover empathy. Humanist Educator, 14(2), 56-62.

Aydın, B. ve Şahin, M. (2017). Psikolojik Danışman Adaylarında Kültürel Duyarlılığı Yordayan Bazı Değişkenler. Buca Ĕgitim Fakültesi Dergisi, 43, 64-77.

Bayles, P. P. (2009). Assesing the intercultural sensitivity of elementary teachers in bilingual schools in Texas school district (Yayımlanmamış doktora tezi). Minnesota Üniversitesi.

Bekiroğlu, O. ve Balcı, Ş. (2014). Kültürlerarası iletişim duyarlılığının izlerini aramak: İletişim fakültesi öğrencileri örneğinde bir araştırma. Türkiyat Araştırmaları Dergisi, 35, 429-459.

Bennett, M. J. (1998). Intercultural communication: A currentperspective. M. J. Bennett (Yay. haz.). Basic Concepts of Intercultural Communication: Selected Readings içinde (ss.134). Boston, MA: Intercultural Press.

Bennett, J., Bennett, M. ve Allen, W. (2003). Developing intercultural competence in the language classroom. D. Lange ve M. Paige (Yay. haz.). Culture as the Core: Perspectives on culture in second Language learning, içinde (ss. 237-270). Greenwich, CT: Information Age Publishing.

Bhavnagri, N. P. (2001). The global village: Migration and education. Childhood Education, 77(5), 256-259.

Black, H. ve Phillips, S. (1982). An intervention program for the development of empathy in student teachers. The Journal of Psychology, 112, 159-168.

Bulduk, S., Usta, E. ve Dinçer, Y. (2017). Kültürlerarası duyarlılık ve etkileyen faktörlerin belirlenmesi: Bir sağlık hizmetleri meslek yüksekokulu örneği. Düzce Üniversitesi Bilimleri Enstitüsü Dergisi, 7(2), 73-77.

Burnett, J., Hamel, D. ve Long, L. (2004). Service learning in graduate counselor education: Deevloping multicultural counseling. Journal of Multicultural Counseling and Development, 32, 190-191.

Chen, G. M. ve Starosta, W. J. (1996). Intercultural communication competence: A synthesis. B. B. Burleson (Yay. haz.). Communication Yearbook 19, içinde. (ss. 358-383). California: Sage Publications.

Chen, G. M. (1997). A review of the concept of intercultural sensitivity. PACA, Hawaii.

Chen, G. M. ve Starosta, W. J. (2000). The development and validation of the intercultural sensitivity scale. Human Communication, 3(1), 1-15.

Çiloğlan, F. ve Bardakçı, M. (2019). The relationship between intercultural sensitivity and English language achievement. Journal of Language and Linguistic Studies, 15(3), 1204-1214.

Deitch Feshbach, N. ve Feshbach, S. (2009). Empathy and education. J. Decety ve W. Ickes (Yay. haz.). The Social Neuroscience of Empathy, içinde (ss. 85-97). The United States: MIT Press.

Demir, S. ve Üstün, E. (2017). Öğretmen adaylarının kültürlerarası duyarlı1ık ve etnik merkezcilik düzeylerinin çeşitli değişkenler açısından incelenmesi. Yüzüncü Yüzyll Üniversitesi Ĕ̈itim Fakültesi Dergisi, 14(1), 182-204.

Diener, E. (1984). Subjective well-being. Psychological Bulletin, 95, 542-75.

Diener, E. ve Biswas-Diener, R. (2008). Happiness: Unlocking the mysteries of psychological wealth. Malden, MA: Blackwell Publishing.

Diener, E., Emmons, R. E., Larsen, R. J. ve Griffin, S. (1985). The satisfaction with life scale. Journal of Personality Assessment, 49, 71-75.

Diener, E. ve Seligman, M. (2002). Very happy people. American Psychological Society, 13(1), 81-84. 
Diener, E. ve Tov, W. (2007). Subjective well-being and peace. Journal of Social Issues, 63(2), 421-440.

Dolby, N. (2012). Rethinking multicultural education for the next generation: The new empathy and social justice. New York: Routledge.

Dökmen, Ü. (1988). Empatinin yeni bir modele dayanılarak ölçülmesi ve psikodrama ile ölçülmesi. Ankara Üniversitesi Eğitim Bilimleri Dergisi, 21, 155-190.

Dökmen, Ü. (1994). Illetişim çatışmaları ve empati. Remzi Kitabevi. İstanbul.

Egelioğlu Çetişli, N., Işık, G., Özgüven Öztornacı, B., Ardahan, E., Özgürsoy Uran, B. N., Top, E. D. ve Ünsal Avdal, E. (2016). Hemşirelik öğrencilerinin empati düzeylerine göre kültürlerarası duyarlılıkları. İzmir Kâtip Çelebi Üniversitesi Sağllk Bilimleri Fakültesi Dergisi, 1(1), 27-33.

Ekong, G., Kavookjian, J. ve Hutchison, A. (2017). Predisposition for empathy, intercultural sensitivity, and intentions for using motivational interviewing in first year pharmacy students. American Journal of Pharmaceutical Education, 81(8), 65-72.

Erdoğan, B. (2018). Sını öğretmenlerinin kültürlerarası duyarlılıkları ve çocuk haklarına yönelik tutumlarının incelenmesi. (Yayımlanmamış yüksek lisans tezi). Çukurova Üniversitesi, Sosyal Bilimler Enstitüsü, Adana.

Fritz, W., Mollenberg, A. ve Chen, G. M. (2002). Measuring intercultural sensitivity in different cultural contexts. Intercultural Communication Studies, 11(2), 165-176.

Gay, G. (2010). Acting on beliefs in teacher education for cultural diversity. Journal of Teacher Education, 61(1/2), 143-152.

Gençöz, T. (2000). Pozitif ve negatif duygu ölçeği: Geçerlik ve güvenirlik çalışması. Türk Psikoloji Dergisi, 15(46), 19-26.

Gordon, S. R. ve Mwavita, M. (2018). Evaluating the international dimension in an undergraduate curriculum by assessing students' intercultural sensitivity. Studies in Educational Evaluation, 59, 76-83.

Güler, B. E. (2012). Yabanc1lara Türkçe öğretiminde “öğretmen” unsuru. International Journal of Social Science, 5(2), 129-134.

Güner, A. ve Levent, A. F. (2018). Halk eğitimi merkezlerinde çalışan öğretmenlerin kültürlerarasi duyarlılık düzeyleri ile empatik eğilimleri arasındaki ilişki. Uluslararası Bilimsel Araştırmalar Dergisi, 3(2), 968-984.

Hammer, M. R., Bennett, M. J. ve Wiseman, R. (2003). Measuring intercultural sensitivity: The intercultural development inventory. International Journal of Intercultural Relations, 27(4), 421-443.

Helmer, J. (2007). Factors influencing the referral of English language learners within an international elementary school: A mixed methods approach (Yayımlanmamış doktora tezi). Minnesota Üniversitesi. Erişim adresi: https://www.proquest.com/libraries/ academic/dissertations-theses/

Hermans, P. (2002). Intercultural education in two teacher-training courses in the North of the Netherlands. Intercultural Education, 13(2), 183-99.

Hollins, E. (2015). Culture in school learning: Revealing the deep meaning. New York, NY: Taylor and Francis.

Holme, K., Petri, N. ve Kirsi, T. (2009). Relationship of gender and academic achievement to Finnish students' intercultural sensitivity. High Ability Studies, 20(2), 187-200.

Howard, G. (2006). We can't teach what we don't know: White teachers, multiracial school. New York, NY: Teacher College Press.

James, M. (2008). Interculturalism: Theory and policy. London: The Baring Foundation.

Jones, T. G. (2002). Relationship between pre-service teachers' beliefs about second language learning and prior experiences with non-English speakers. L. Minaya-Rowe, (Yay. haz.), Teacher training and effective pedagogy in the context of student diversity, içinde (ss. 3964). Greenwich, CT: IAP Information Age Publishing.

Kahneman, D. ve Krueger, A. B. (2006). Developments in the measurement of subjective wellbeing. Journal of Economic Perspectives, 20, 3-24. 
Korkmaz-Aslan, G., Kartal, A., Turan, T., Taşdemir-Yiğitoğlu, G. ve Kayan, S. (2019). Intercultural sensitivity of university students studying at health-related departments and some associated factors. FNJN Florence Nightingale Journal of Nursing, 27(2), 188-200.

Köker, S. (1991). Normal ve sorunlu ergenlerin yaşam doyumu düzeylerinin karşılaştırılması (Yayımlanmamış yükseklisans tezi). Ankara Üniversitesi, Sosyal Bilimler Enstitüsü, Ankara.

Köse, S., Tetik, S. ve Ercan, C. (2001). Örgüt kültürünü oluşturan faktörler. Celal Bayar Üniversitesi İBF Dergisi, 7(1), 219-242.

Kürtüncü, M., Arslan, N., Çatalçam, S., Yapıcı, G. ve Hırçin, G. (2018). Yataklı tedavi kurumlarında çalışan hemşirelerin kültürlerarası duyarlılıkları ile sosyo-demografik özellikleri ve empati düzeyleri arasındaki ilişkisi. Hemşirelikte Araştırma Geliştirme Dergisi, 20(1), 44-56.

Ladson-Billings, G. (2006). Yes, but how do we do it? Practicing culturally relevant pedagogy. J. Landsman ve C. W. Lewis (Yay. haz.), White Teachers/Diverse Classrooms: A Guide to Building Inclusive Schools, Promoting High Expectations, and Eliminating Racism içinde (ss. 29-42). Sterling, VA: Stylus.

Lucas, R. E. ve Diener, E. (2008). Personality and Subjective Well-Being. O. P. John, R. W. Robins ve L. A. Parwin (Yay. haz.). Handbook of Personality: Theory and Research, içinde (ss.795-814). New York: The Guilford Press.

McAllister, G. ve Irvine, J. J. (2000). Cross cultural competency and multicultural teacher education. Review of Educational Research,70(1),2-34.

McAllister, G. ve Irvine, J. J. (2002). The role of empathy in teaching culturally diverse students: A qualitative study of teachers' beliefs. Journal of Teacher Education, 53(5), 433-443.

Menardo, D. A. (2017). Mindfulness, empathy and intercultural sensitivity amongst undergraduate students (Yayımlanmamış doktora tezi). Alliant International Üniversitesi, California. Erişim adresi: http://eric.ed.gov/?id=ED577814

Meydanlığlu, A., Arıkan, F. ve Gözüm, S. (2015). Cultural sensitivity levels of university students receiving education in health disciplines. Advances in Health Sciences Education, 20(5), 1195-1204.

Micó-Cebrián P. ve Cava, M. J. (2014) Intercultural sensitivity, empathy, self-concept and satisfaction with life in primary school students. Journal for the Study of Education and Development, 37(2), 342-367.

Micó-Cebrián, P., Cava, M. J. ve Buelga, S. (2019). Sensibilidad intercultural y satisfacción con la vida en alumnado autóctono e inmigrante. Educar, 55(1), 39-57.

Milner, H. R. (2010a). Start where you are, but don't stay there. Cambridge: Harvard University Press.

Milner, H. R. (2010b). What does teacher education have to do with teaching: Implications for diversity study? Journal of Teacher Education, 61(1-2), 1118-1131.

Otten, M. (2003). Intercultural learning and diversity in higher education. Journal of Studies in International Education, 7(12), 12-26.

Öğüt, N. (2017). Kültürlerarasi duyarlılık düzeyi ile etnik merkezcilik, yaşam doyumu ve mutluluk düzeyleri arasındaki iliş̧kinin incelenmesi (Yayımlanmamış doktora tezi). Selçuk Üniversitesi Sosyal Bilimler Enstitüsü, Konya.

Öğüt, N. ve Olkun, E. O. (2018). Üniversite öğrencilerinin kültürlerarası duyarlılık düzeyi: Selçuk Üniversitesi örneği, Selçuk Illetişim, 11(2), 54-73.

Pavot, W. ve Diener, E. (1993). Review of the satisfaction with life scale. Psychological Assessment, 5, 164-172.

Ruan, J. (2014). Using the ABCs to support intercultural understanding. C. Finkbeiner, A. Lazar ve P. Schmidt (Yay. haz.). Getting to Know Ourselves and Others: A Less Travelled Path to Intercultural Understanding. Literacy, Language and Learning Series, içinde. Information Age Publishing: Charlotte, NC. 
Spinthourakis, J. A., Karatzia-Stavlioti, E. ve Roussakis, Y. (2009). Pre-service teacher intercultural sensitivity assessment as a basis for addressing multiculturalism. Intercultural Education, 20(3), 267-276.

Spitzberg, B. H. ve Changnon, G. (2009). Conceptualizing intercultural competence. D. K. Deardorf (Yay. haz.). The SAGE Handbook of Intercultural Competence, içinde (ss. 252). Thousand Oaks, CA: Sage.

Sue, D. W. ve Sue, D. (2012). Counseling the culturally diverse: Theory and practice. New York, NY: John Wiley \& Sons.

Talib, M. T. (2006). Why is it so hard to encounter diversity? M. T. Talib (Yay.haz.). Diversity a Challenge for Educators. Research on Educational Sciences 27, içinde (ss. 139-156). Turku: Finnish Educational Research Association.

Taylor, S. E., Peplau, L. A. ve Sears, D. O. (2012). Sosyal psikoloji. Kişilerarası Sevgi ve Çekicilik içinde (ss. 248). İmge Kitabevi, Ankara.

Tettegah, S. ve Anderson, C. J. (2007). Pre-service teachers' empathy and cognitions: Statistical analysis of text data by graphical models. Contemporary Educational Psychology, 32(1), 48-82.

Tov, W. ve Diener, E. (2008). The well-being of nations: Linking together trust, cooperation, and democracy. B. A. Sullivan, M. Snyder, ve J. L. Sullivan (Yay. haz.), Cooperation: The political psychology of effective human interaction, içinde (ss. 323-342). Malden, MA: Blackwell

Tuncel, İ. ve Arıcioğlu, A. (2018). The Factors affecting the intercultural sensitivity perception level of psychological counseling and guidance students. International Education Studies, 11(3), 61-69.

Ward, C. (2001). The A, B, Cs of acculturation. D. Matsumoto (Yay. haz.). The Handbook of Culture and Psychology içinde (ss. 411-445). Oxford: Oxford University Press.

Watson, D., Clark, L.A. ve Tellegen, A. (1988). Development and validation of brief measure of positive and negative affect: The PANAS scales. Journal of Personality and Social Psychology, 54(6), 1063-1070.

Ünlü, İ. ve Örten, H. (2013). Öğretmen adaylarının çok kültürlülük ve çok kültürlü eğitime yönelik algılarının incelenmesi. Dicle Üniversitesi Ziya Gökalp Ĕ̈itim Fakültesi Dergisi, 21, 287302.

Üstün, E. (2011). Öğretmen adaylarının kültürlerarası duyarlılı ve etnik merkezcilik düzeylerini etkileyen etmenler (Yayımlanmamış yüksek lisans tezi). Yıldız Teknik Üniversitesi, Sosyal Bilimler Enstitüsü, İstanbul.

Vilà, R. (2010). La competencia comunicativa intercultural en alumnos de Enseñanza Secundaria de Catalunya. Revista Electrónica de Investigación y Didáctica, 3, 88-108.

Westrick, J. M., Celeste, Y. ve Yuen, M. (2007). The intercultural sensitivity of secondary teachers in Hong Kong: A comparative study with implications for professional development. Intercultural Education, 18(2) 129-145.

Yılmaz, F. ve Göçen, S. (2013). Sınıf öğretmeni adaylarının kültürlerarası duyarlılık hakkındaki görüşlerinin farklı değişkenlere göre incelenmesi. Adiyaman Üniversitesi Sosyal Bilimler Enstitüsü Dergisi, 6(15), 374-392.

Yuen, C. Y. M. ve Grossman, D. L. (2009). The intercultural sensitivity of student teachers in three cities. Compare: A Journal of Comparative and International Education, 39(3), 349-365.

\section{ExtendedAbstract}

\section{Introduction}

Individuals need to have more intercultural connections, communication and interactions needs because of new developments in economic, social, political and educational fields in today's World. As cultural diversity arises, the need for interculturally sensitive teachers increases as well for an effective and equal education possibility for students. Interculturally sensitive teachers have 
a crucial role for students to reach equal education conditions and democratic learning environment (Ünlü \& Örten, 2013).

Intercultural communication model consists of intercultural sensitivity, intercultural awareness and intercultural adroitness. Intercultural sensitivity which refers to affective dimension of intercultural communication is defined as "“an individual's ability to develop positive emotion towards understanding and appreciating cultural differences that promotes appropriate and effective behavior in intercultural communication" (Chen \& Starosta, 1996). It can be stated that for teachers, empathy is the concept that provides a link function for the cultural norms and values that students experience in and out of school (Howard, 2006; Ladson-Billings, 2006; McAllister \& Irvine, 2002; Milner, 2010b). Empathy is seen as an important intervention for developing students' learning outcomes in multicultural classroom setting (Dolby, 2012). When the needs of today's World are taken into account, empathy is inevitably one of the competences that candidate teachers need to gain during their teaching training process (Aspy,1975; Black \& Phillips, 1982; Tettegah \& Anderson 2007).

Empathy is "to put oneself in someone's place and to understand someone's emotions and thoughts correctly" (Dökmen, 1994) and emphatic tendency is "the potential for empathy ability in daily life" (Dökmen, 1988). Individual can have a better understanding for statements and emotions and later give effective reactions during communication by means of empathy which has a central role for intercultural sensitivity (Chen, 1997). Subjective well-being helps individuals feel better and be more successful in interpersonal relationships (Diener \& Seligman, 2002). Subjective well-being refers to individuals' cognitive evaluations about their life satisfaction in general and affective evaluation consisted of two components such as positive and negative affect (Diener, 1984). Subjective well-being often refers to happiness more colloquially (Lucas \& Diener, 2008). In literature review, happiness was seen to be positively correlated with intercultural sensitivity (Öğ̈̈t, 2017). Also, intercultural sensitivity was found to be positively correlated with empathy and life satisfaction-a cognitive component of subjective well-being (Micó-Cebrián \& Cava, 2014).

The purpose of this study was to examine predictive power of empathy and subjective well-being on intercultural sensitivity among teacher candidates. Another purpose in this study was to examine whether intercultural sensitivity differs in terms of some socio-demographic variables such as gender, teaching program type, going abroad experience, perceived language level and having acquaintances or close friends from different national or cultural backgrounds.

\section{Method}

A descriptive correlational design was utilized in this study. The dependent variable was intercultural sensitivity and dependent variables were empathic tendency and subjective wellbeing. The study group consists of 355 teacher candidates ( 253 females $71.3 \%, 102$ males $28.7 \%$ ) from different teaching departments of Faculty of Education in a state-funded university on the Mediterranean region of Turkey. Participants ranged in age between 20 and 34 years.

"Intercultural Sensitivity Scale," the "Empathic Tendency Scale", the "Satisfaction with Life Scale" and "Positive and Negative Affect Schedule" and finally, the "Personal Information Form" were used for data collection. In data analysis, correlation analysis, multiple regression analysis, independent samples t- test and one-way analysis of variance (ANOVA) were performed.

\section{Results}

According to study findings, intercultural sensitivity was positively correlated with empathic tendency $(\mathrm{r}=.44, \mathrm{p}<.01)$ and also positively correlated with subjective well-being $(\mathrm{r}=.34, \mathrm{p}<.01)$ among candidate teachers. Empathic tendency and subjective well-being scores together accounted for $21 \%$ of the variance in intercultural sensitivity. Other findings of this study indicated that empathy and subjective well-being were found to be significant predictors of intercultural sensitivity among teacher candidates. 
According to socio-demographic variables results, firstly, although intercultural sensitivity scores did not significantly differ in terms of gender $\left[\mathrm{t}_{(353)}=1.80 ; \mathrm{p}>.05\right]$, significant difference has been found for teaching program type $\left[\mathrm{f}_{(7-347)}=4.33 ; \mathrm{p}<.05\right]$. This intercultural sensitivity mean score difference was for English teacher candidates among other candidate students' groups such as candidates of science teachers, mathematics teachers, kindergarten teachers and psychological guidance and counseling students. Secondly, intercultural sensitivity mean scores differed significantly in terms of going abroad experience variable $\left[\mathrm{F}_{(3-351)}=4.33\right.$; $\mathrm{p}$ <.05]. Intercultural sensitivity mean score of teacher candidates with going abroad experience up to twelve months and thirty days were significantly higher than mean scores of teacher candidates with no going abroad experience and one-year experience. As for perceived foreign language level, intercultural sensitivity mean score differed significantly among teacher candidates $\left[\mathrm{F}_{(3-351)}=5.71 ; \mathrm{p}<.05\right]$. The intercultural sensitivity mean score of teacher candidates who perceive their foreign language as advanced level was significantly higher than the ones who stated that they do not have any foreign language knowledge and also the ones with beginner level. Finally, mean score of intercultural sensitivity differed significantly in terms of having acquaintances from different national or cultural background $\left[\mathrm{t}_{(353)}=4.57 ; \mathrm{p}<.05\right]$ and also having close friends from different national or cultural backgrounds $\left[\mathrm{t}_{(353)}=2.92 ; \mathrm{p}<.05\right]$ comparing the ones who do not have any acquaintances or close friends from different national or cultural background among teacher candidates.

\section{Conclusion and Discussion}

Findings of present study demonstrated that intercultural sensitivity, empathic tendency and subjective well-being were all positively correlated with each other among teacher candidates. Other findings of this study indicated that empathy and subjective well-being were found to be significant predictors of intercultural sensitivity among teacher candidates. According to sociodemographic variables results, although intercultural sensitivity scores did not differ significantly in terms of gender, significant difference has been found for teaching program type, going abroad experience, perceived foreign language level and having acquaintances or close friends from different national or cultural backgrounds among teacher candidates.

In present study, empathy was found to be a predictor of intercultural sensitivity. This finding supports some researches (Abasl1, 2018; Aydın \& Şahin, 2017; Egelioğlu Çetiş̧li et al., 2016; Micó-Cebrián, Cava, \& Buelga, 2019) in literature review. It can be concluded that empathy helps individuals understand cultural differences such as values, beliefs, language, dialects, behaviours etc. Secondly, subjective well-being was seen to be a predictor of intercultural sensitivity in this study. Similarly, some studies which examined intercultural sensitivity with life satisfaction- a cognitive component of subjective well- being (Micó-Cebrián \& Cava, 2014) and happiness (Öğ̈̈t, 2017) concluded that these variables increase the intercultural sensitivity. Indeed, subjective well-being may foster peace attitutes as it can influence the way individuals perceive and relate to each others (Tov \& Diener, 2008). 